\title{
Towards a Third Generation of Global Governance Scholarship
}

This is the final typeset and copyedited PDF version. The chapter should be cited as:

David Coen and Tom Pegram, 'Towards a Third Generation of Global Governance

Scholarship', Global Policy, Global Policy, Volume 9, Issue 1 (February 2018), 107-113.

\begin{abstract}
Global governance is widely viewed as in crisis. Deepening interdependence of cross-border activity belies the relative absence of governance mechanisms capable of effectively tackling major global policy challenges. Scholars have an important role to play in understanding blockages and ways through. A first generation of global governance research made visible an increasingly complex and globalising reality beyond the interstate domain. A varied second generation of scholarship, spanning diverse subfields, has built upon this 'signpost scholarship' to generate insight into efforts to manage, bypass and even - potentially - transcend multilateral gridlock to address pressing transboundary problems. This article plots a course towards a 'third generation' of global governance research, serving to also introduce a special section which brings together leading scholars in the field of global governance, working across theoretical, analytical and issue-area boundaries. This collaborative endeavour proposes to advance a convergence, already underway, across a theoretically and empirically rich existing scholarship, distinguished by a concern for the complexity of global policy delivery.
\end{abstract}




\section{Introduction}

Although its conceptual, analytical and theoretical boundaries may be hotly debated, global governance is widely viewed as a vital component to addressing transboundary common goods challenges, from large-scale violence to sustainable development, health to climate change, bio-pathogen containment to financial disruption. As Martin Wolf (2012) of the Financial Times suggests, humanity's efforts to overcome the tragedy of the global commons 'could prove to be the defining story of the century'. Martin Rees (2014) agrees, suggesting that existential risks make it unlikely that humanity will reach the end of this century without major changes. But what is global governance? How might it be harnessed to ensure human society meets the challenges posed by a rapidly globalising reality? And can the failings of the inherited global institutional order be effectively remedied within a global context of accelerating power fragmentation, legitimacy deficits and populist contestation?

This special section of Global Policy seeks to reflect upon the distance travelled by global governance scholarship in recent years, as well as identify promising lines of future inquiry. As will be outlined, a first generation of global governance research has paved the way for a probing and expansive second generation of scholarship, rooted in International Relations (IR) but also branching out to international law, comparative politics and beyond. ${ }^{1}$ It is the contention of the special section editors that there is much to be gained from further enabling scholarly exchange across this theoretically and empirically rich, but disparate, body of work, towards what we term a third generation of global governance research. The generational metaphor is employed not for arbitrary categorisation or labelling, but rather to indicate trajectory, points of analytical transition and legacies, as well as lines of flight towards more systematic inter- and cross-disciplinary learning. 
This collection builds upon a commentary published in Governance by Coen and Pegram (2015), as well as an international symposium held at University College London (UCL) in November 2015 with colleagues working at the cutting-edge of global political research, which served as a launching pad for the call for a third generation of global governance research. Contributors to this special section are all leading pioneers in global governance thinking. In showcasing their research, as well as reflections on the state of the field, this collection hopes to galvanise further scholarly innovation and inquiry into, ultimately, how humane and effective governance might be achieved on a global scale.

\section{A first generation of global governance scholarship}

Within academic circles, global governance has a long if under-appreciated pedigree in IR, but also in other fields, including political geography, law and history. In recent decades, it has been largely subsumed under the umbrella of IR or understood, for all intents and purposes, to be synonymous with international organisations. However, there is good reason to consider global governance a distinct, if not an entirely demarcated, field of inquiry in its own right. A resurgence of interest in global governance has been felt within the IR fraternity. 2016 witnessed the first article in the IR flagship journal, International Organization, to ever explicitly reference global governance in its title (Abbott et al., 2016). Presented by its advocates as an antidote to a field prone to insularity and over-theorisation (Weiss and Wilkinson, 2014), others dispute any meaningful demarcation between global governance and IR (Finnemore, 2014). This special section seeks to deepen understanding of an incipient global governance pivot, observable within and beyond the bounds of IR, one which is seeking to overcome the paradigmatic 'isms' or doctrines of realism, liberalism and constructivism through critical reflection, empirical reflexivity and mid-range theorisation. 
Global governance scholarship remains firmly rooted in the liberal rationalist traditions of IR. The disciplinary turn in the 1970 s towards international organisation and regime theory, spearheaded by Keohane and Nye (1977), continues to provide the bedrock inspiration for much contemporary debate on global governance. A first generation of global governance research, principally in IR, focused almost exclusively on formal mechanisms of interstate relations within public multilateral institutions, such as the United Nations and the World Bank. This body of liberal institutionalist work uncovered the scope conditions for multilateral cooperation through international organisations, as well as the potential for effective regime management (Young, 1980; Snidal, 1985). The functional premise of much of this work was bolstered by developments in the real world. As Hale, Held and Young (2013) document, the end of the Cold War ushered in a golden age of interstate multilateralism, reaching its apex in the early 1990s, with achievements such as the Rio Declaration of 1992 and the 1994 Marrakesh Agreement. However, these successes often reflected unusual conditions, which have since undergone a marked deterioration just as the scope of global regulatory ambition has grown.

Although marginal to the dominant realist and rational institutionalist paradigms of the era, the influence of Cox (1981), Ruggie (1982), Strange (1986) and other scholars working from diverse perspectives throughout the 1980s, including neo-Gramscian theory, constructivism, and international political economy, resonated deeply, especially outside the US IR academy. They were particularly exercised by what they perceived to be a status quo bias in dominant rationalist theoretical frames, one which screened out deeper power asymmetries, private authority, ideology and value and legitimacy conflict, issues which would remerge with a vengeance in the post-2000s (Hurrell, 2007). Their work paved the way for the critical appraisal of existing analytical toolkits which took hold in the 1990s, with pathbreaking 
scholars, such as Cerny (1993), Held (1995) and Rosenau (1995), expanding our range of possibilities, not only in terms of making visible an increasingly complex and globalising governance reality, but also in explaining how global governance structures actually work in practice.

This desire to make comprehensible a rapidly changing world order also resonated within the policy community, as evidenced in the publication of the Commission on Global Governance Report (1995). Weiss (2011, p. 9) has described the rise of global governance as a 'shotgun wedding between academic theory and practical policy in the 1990s'. If this shotgun wedding had the virtue of provoking new thinking in both academic and policy circles, it has also muddied the conceptual waters.

Reflecting on the origins of a global governance terminology, for many observers in the early 1990s, global governance appeared to be 'virtually everything', a descriptive catch-all for the fact that 'we really don't know what to call what is going on' (Finkelstein, 1995, p. 368). Finkelstein might have tempered this claim by reference to the paradigmatic shift occurring simultaneously in political science from the systematic study of 'government' to 'governance' (Stoker, 1998). However, the two fields of IR and political science have remained largely estranged, with the notable exception of European comparative political research (Jupille and Caporaso, 1999).

Association with a policy programme of 'managing globalisation' also raised concerns regarding inbuilt teleological commitments (Dingwerth and Pattberg, 2006). Eagleton-Pierce (2014, p. 7) locates the origins of global governance partly in 'the universalisation of a business-centred vision of political life'. This origin story has led some scholars to dismiss the 
concept (Mazower, 2014). However, it does not necessarily follow that global governance will forever be inextricably tied to the circumstances of its birth. It is incumbent on global governance scholars to 'guard against the risk of reifying certain concepts from their historical gestation' (Eagleton-Pierce 2014, p. 8). One way forward, as Zürn (this section, p. \#\#) remarks, is to ensure that power and hierarchy are included within any conceptualisation of global governance, thereby avoiding the 'traps of technocracy, neoliberal hegemony, or idealism'.

Global governance remains subject to multiple and competing reconceptualisations, largely responsive to the normative disposition of its wielder. ${ }^{2}$ Recent contributions eschew definition altogether, understanding global governance as a 'legitimate set of questions about how the world is governed and ordered at all levels and in every historical period' (Weiss and Wilkinson 2015, p. 405). In other words, if observers find the concept of global governance useful, then they should first seek to describe how it has changed over time within specific historical contexts, and explain that change. However, other scholars boldly call for a positive theory of global governance, one which decisively moves beyond negative descriptions of global governance as simply post-internationalist (Zürn, this section). Whether or not global governance is a 'theory in the making' (Dingwerth and Pattberg, 2006, p. 199), a second generation of global governance scholarship, drawing upon a diverse set of theoretical and methodological insights, has made significant advances to explaining global political outcomes. Indeed, Hale and Held (this section) provide a compelling demonstration of how descriptive inference based on rigorous conceptual identification can yield robust theorisation, ultimately helping us make sense of when and why global governance activities succeed or fail.

\section{A second generation of global governance scholarship}


Systematising knowledge on global governance activities has been made possible by the dramatic broadening of substantive scope in the past two decades. If much early global governance scholarship focused on describing accelerating change in the global economic order, reflecting pioneering work in the field of international political economy, the research landscape today is much more diverse. This second generation of global governance scholarship is eclectic, rooted in IR, but informed by research activity in cognate fields such as sociology, international law, economics, public policy and business management, and extending into less orthodox disciplinary and substantive domains, including disaster risk, computer science, climatology or health, to name but a few (Pegram and Acuto, 2015). However, as a core research agenda, global governance scholarship still generally restricts itself to theoretical and empirical application within a pluralist understanding of global politics, shading into comparative politics and international law (Coen and Pegram, 2015).

This generation of global governance scholarship comprises a rapidly growing but disparate body of cutting-edge research, united (broadly) in a concern for the complexity of achieving collective action on an unprecedented scale in an age of 'radical uncertainty' (King, 2016). At the risk of over-stylisation, we identify two principle thrusts in current research efforts: First, what might be termed a macro-structural account of global governance systemic change, engaged directly with the question of how power is exercised and with what effect under conditions of fragmentation, legitimation problems and regime complexity (see Hale and Held; Zürn, this section). This is geopolitical power framed not as determinative, based on a crude assessment of distribution of capabilities, but rather as a shape-shifting variable which must be built into more sophisticated accounts of global governance processes and outcomes (Paris, 2015). A second strand of scholarship focuses upon micro-process accounts of dynamic regulation, post-delegation behaviour by purposive agents and growing informality within 
governance systems (see Haufler; Marx and Wouters, this section). This drive towards understanding 'the micro' reflects, among other things, the imperative of addressing global public policy delivery, or implementation, beyond institutional creation and design.

This new generation of global governance scholarship aspires to deliver on the analytical precision of specialisation, coupled with the normative appeal of connecting diverse practices, structures and processes towards capturing the 'big picture', with global governance understood as the sum total of what happens at all levels of governance. As Weiss and Wilkinson (2015, p. 402) argue, 'one of the assets of the adjective in global governance is that it infers the "big," the "macro," the "total", without necessarily implying planetary coverage. Cutting-edge scholarship is probing the consequences of power fragmentation and growing informality for explaining large-scale systemic change (Zürn, 2018, forthcoming). Relatedly, counter-hegemonic activities by rising powers are focusing minds on the importance of 'legitimate authority' (Lake, 2010), as well as understanding power differentials not only in terms of material indices, but also in their historical and geographical context (Hurrell, 2017). Scholars have also amplified the important role of agency for understanding global political outcomes, interrogating, in particular relations among 'the governors' and 'the governed' (Avant et al., 2010). As these analysts make clear, while individuals' decisions are conditioned, they are almost never determined by structures alone. Such relational and contingent causal properties become particularly salient in a global governance reality informed by 'liquid', as well as 'solid', forms of authority (Krisch, 2017).

Modification of principal-agent frameworks has also yielded important new insights into postdelegation behaviour by independently-minded non-state actors (Coen and Thatcher, 2005; Abbott et al., 2015; 2017). Understanding the dynamic effects of regulation becomes 
increasingly important as we enter an ever more variegated and pluralist landscape in terms of agency, structural overlaps and normative ordering. Others have taken on the ambitious task of seeking to explain the underlying structural changes which shape the global social realm, building upon pioneering work in sociology and organisational studies (see Jessop, 1998; Albert et al., 2010; Abbott et al., 2016). However, the difficulty of explaining (as opposed to analytically describing) change within multi-scalar complex social systems remains a deeply challenging - and challenged - enterprise (DeLanda, 2006).

\section{Towards a third generation of global governance scholarship}

This call for a third generation of global governance research underscores the potential for intra- and cross-disciplinary learning, taking advantage of insights gained at both the macroand micro-level. If this body of work lacks a unifying principle, we can discern an emerging core global governance research agenda driven by a range of deeply held pragmatic and shared concerns; above all, the imperative of elaborating coherent and realistic solutions to global public policy challenges. As a first cut, we have identified four areas of inquiry intended to illustrate the scope and specificity of some of the issues which underpin a purposive turn in global governance scholarship.

- Establishing boundaries. What is actually 'global' in global governance? What is the role of scale and disaggregation in understanding global governance outcomes? Where we encounter regime complexity, what potential incompatibilities and tensions arise? What is the significance of the 'hybrid' fusing of public and private modes of governance to create new global regimes?

- Whither theory? What kind of global governance theorisation can the field aspire to? Is descriptive or conditional theory sufficient, or should scholars also be pursuing 
positivist explanatory theory? How can theoretical reconceptualisations of global governance open-up new causal pathways for investigation?

- Implementation politics. What are some of the transferable tools, mechanisms and theories which can underpin a viable model of global-to-local public policy delivery? How can we better account for the complex motivations of global governance participants at all levels? What are the ethical imperatives which must inform efforts to enhance coordination and governance on a global scale?

- What works? How do we move from bad to good global governance? What are the key drivers of change in global politics? What is the nature and source of power, the distribution of power, and the structural conditions which enable or impede 'good global governance'? How do diverse regulatory instruments work, when and why do they matter, and with what effect?

We now expand upon some of these questions in light of contributions to this special section and the wider scholarship.

\section{A. ESTABLISHING BOUNDARIES}

We need to get a better handle on boundary questions which implicitly inform the conceptual and analytical value of global governance. What is actually 'global' in global governance? While some issues become global governance concerns when they spill over borders (e.g. infectious disease epidemics), others are irreducibly global concerns by their nature (e.g. climate change). The analytical challenge of locating the 'global' in global governance is compounded by the fluid quality of authority relationships which inform the interplay between national political systems and other function systems of world society. As Zürn (this section, p. \#\#) observes, if national political systems are defined primarily by territorial borders and, 
secondarily, by the boundaries of the function system within these borders, the global governance system presents the opposite: defined principally by global function systems, such as economy, science, art and sport, and only secondarily by territorial borders. This reality is producing increasingly serious legitimation problems for global governance systems which have only ever had a tenuous claim to legitimate meta-authority.

One potential consequence is populist contestation of governance arrangements above the state. Reflecting on the decision of the United Kingdom to withdraw from the European Union (Brexit), Mary Kaldor (2016) laments the easy seduction of the phrase 'take back control'. As Kaldor reflects, isn't 'our best hope of being able to influence the decisions that affect our lives...through an institution like the European Union?' Brexit pitted national sovereignty and political identities against powerful globalising forces, with dramatic effect. Boundary conflicts between different spheres of territorial and functional authority and - most pressingly - the relative paucity of tools to manage such interface conflicts are therefore of vital concern (Zürn, this section p. \#\#), especially as functional regime arrangements become more and more complex and the distinction between public and private authority is increasingly blurred through multi-actor initiatives (Haufler, this section).

As Yves Tiberghien (2017) argues, for too long, scholars have treated individual areas of global governance - be they trade, economy, health, law or scientific cooperation - as distinct games, focusing on incremental gains at the Pareto frontier. We need to pay more attention to where fundamental differences in interests erupt within larger, often overlapping, regime complexes. As Haufler (this section, p. \#\#) points out, this is not a straightforward undertaking as issue boundaries are not static but 'evolve and change over time'. A political economy perspective may assist us in this task, drawing attention to the interaction of markets with political authority 
and the disjuncture between global scales of production and national regulation (Haufler, this section, p. \#\#). This is reflected, for example, in strident criticism of the World Bank - a principal focal actor in development - for its ambivalent position on human rights protection (Staufenberg, 2015). One task for scholars then is to reflect on how such apparent contradictions can be reconciled. However, equally important is to identify and explain compatibility, even reinforcement over time, of governance logics and mechanisms across sectoral divides. For example, Marx and Wouters (this section), note that while voluntary sustainability standards are predominantly an instrument of private global governance, they often have their roots in public international law and can help reinforce public regulations.

\section{B. WHITHER THEORY?}

The fluid boundaries of global governance as a field of inquiry are also reflected in the debate on the role of theory. Part of the appeal of global governance lies in its more plural intellectual orientation compared to IR, which according to some observers has left theory behind (Mearsheimer and Walt, 2013). However, systemic global governance theory remains embryonic, too often reduced to negative descriptions of global governance as "postinternationalist', with scholars uncertain regarding the extent to which outcomes in any one issue-area are contingent upon context and complex configurations and thus resistant to generalisation. Nevertheless, reflecting Katzenstein and Sil's (2008) call for eclectic theorising, there is much evidence of empirically-driven theoretical innovation occurring at lower levels of abstraction (see Hale and Held, this section). Transgression across theoretical and disciplinary boundaries are also readily apparent, observable in global politics and sociology (Albert et al., 2013), international law (Abbott, 2005), comparative politics (Farrell and Newman, 2015), history (Taylor, 2007), psychology (Hall and Ross, 2015) and complexity theory (Root, 2013), to name but a few. 
Whether global governance presages 'the emergence of a new joint discipline' (Koh, Abbott, and Young, 1992) or a step into meta-theory, the building of more robust bridges across theoretical archipelagos is a positive development. Rather than being viewed as a deficit, the absence of a core 'global governance theory' can also be viewed in a positive light as having encouraged scholars to make use of the field as a site for theoretical experimentation. Disciplinary borders have been crossed. However, efforts have also been made to retain the distinctive value of diverse perspectives. In tracing connections across international law (IL), European public policy (EPP) and IR, Coen and Pegram (2015) highlight the distinctive strengths of each field, whether that be EPP's forensic analysis of cross-national institutional layering, IL's longstanding concern for normativity, or IR's direct engagement with the consequences of power fragmentation. Of course, the extent of cross-disciplinary borrowing to illuminate global governance processes and outcomes depends in large part on the questions posed and the substantive issue(s) under examination. While Haufler (this section) highlights how a political economy approach can shed new light on the study of transnational production, Marx and Wouters (this section) adapt organisational concepts and theories to examine the internal dynamics of global governance processes and outcomes.

Global governance emerged as a response to an empirical world of growing transboundary complexity, seeking to capture both a novel pluralisation and structural density in world politics. Moving beyond this descriptive endeavour, global governance scholars must ensure that theoretical innovation does not play out in a vacuum, that it remains responsive to how the world is changing. We already observe sustained efforts in this direction, with the proliferation of descriptive and conditional theory, underpinned by empirically rich research agendas. This includes regime complex theory (Raustiala and Victor, 2004), fragmentation (Biermann et al., 
2009), orchestration (Abbott et al., 2015), experimental governance (De Búrca et al., 2015), contested multilateralism (Morse and Keohane, 2014), and legalisation (Abbott et al., 2000). Zürn (this section, p. \#\#) proposes an ambitious general theory of global governance focused 'on the most important features of the global governance system and their behavioural consequences'. Recent contributions, drawing on structural theories of differentiation and organisational ecology, also strike out in this direction (Abbott et al., 2016; Albert et al., 2013). Other scholars propose theorising inductively, with Hurrell calling on scholars to 'make theory locally, but make it portable' ${ }^{3}$ Both approaches are likely to yield important new avenues for theorising global governance.

\section{IMPLEMENTATION POLITICS}

Drawing up international agreements in Geneva or New York is relatively easy compared to their delivery. Many of the governance challenges that we face today are not necessarily all that complex; it is the politics that is difficult. Efforts to circumvent multilateral gridlock and connect international regulatory arrangements to the realities of local implementation politics are increasingly evident across domains (Hale and Held; Haufler; Marx and Wouters, this section). Well understood in the fields of public administration and organisational studies, implementation typically involves street-level bureaucrats who must negotiate between civil society, consumers and market actors to get things done. Local actors who were absent from the negotiation of international standards, may assume central importance at the implementation stage. As Zürn (this section) notes, local contestation of international institutions takes place in the form of politicisation. Importantly, rather than viewing it as a threat to the efficient running of the system, Zürn (this section, p. \#\#) argues that such politicisation should be reframed as an opportunity to 'relegitimise' global governance through meaningful societal debate. Indeed, as the contribution by Marx and Wouters (this section) 
suggests in relation to VSS monitoring, efforts at legitimisation (and relegitimation) of supposedly technical global governance domains will likely require an honest reckoning on the part of aspirant-global governors with their critics and a willingness to meaningfully respond.

Global governance scholarship needs to pay attention to the local politics of implementation which ultimately shape outcomes. Moving to the local level, different problems are going to require tailored interventions based on different regulatory logics. If diverse regulatory instruments are important - from legal sanctions, to taxes, certification schemes, public information campaigns or voluntary pledges - there is much work to be done in specifying exactly how they matter, under what conditions, and with what effect. In mapping out pathways beyond gridlock, Hale and Held (this section) note the variable impact of distinct pathways under different conditions and the fallacy of 'one-size-fits-all' solutions.

On this point, domestic political scholarship has much to offer, and indeed much to gain, in driving forward a research agenda which explicitly situates a substantial body of scholarship on domestic regulation within a rapidly globalising reality. For example, what are the conditions under which investment in common goods-oriented global governance action can lead to domestic political gains (Tiberghien, 2015)? Both fields of regulation and global governance would do well to reflect critically on the limitations of existing theoretical frames. For starters, there remains a pressing need to better understand cognitive heuristics and bounded rationality, including 'informal methods, ideologies, ideas, and rules of thumb' which guide global governance participants, above and beyond the constraints and/or enabling functions derived from principal-agent models (Alter and Meunier, 2009, p. 18). Understanding the complex motivations of decision-makers at all levels of governance is 
highly salient to galvanising action, for example, by devising innovative auditing schemes to ensure implementation of global standards (Marx and Wouters, this section).

Ultimately, the politics of implementation demands that scholars seek to connect multi-level regulatory systems to altering politics in a particular territory. With this mind, it is equally necessary that efforts to advance effective global regulation do not lose sight of the supposed beneficiaries (Koenig-Archibugi and MacDonald, 2013). As Zürn (this section, p. \#\#), reminds us, 'there is an urgent need to pay attention to the losers of globalisation'. Similarly, Hale and Held (this section, p. \#\#) highlight the importance of focusing on 'the impact of global governance on human welfare'. Global governance programmes are most often received by populations in the global south or east, far away from the international headquarters where they are devised. As Acharya (2014) cautions, it is incumbent on global governance scholars to avoid the danger of reifying western or regional knowledge to the exclusion of different kinds of knowledge. Indeed, Haufler (this section, p. \#\#) identifies the absence of global south scholars as a failing of the global governance literature in general.

\section{WHAT WORKS?}

Finally, perhaps the most pressing issue in global governance today is: what works? Global governance, however partial, is not hypothetical. What can we learn from really-existing global governance regimes, processes and outcomes? Can we identify high quality comparative global governance research which firmly grounds its theoretical claims in robust empirical evidence? The general consensus appears to be that the legacy institutions of the post-WWII settlement are failing to serve as a useful platform for action and are increasingly 'not fit for purpose'. How then can we reverse this trend and enable a shift from bad to good governance; what is the nature and source of power, the distribution of power, and the structural 
conditions which is impeding good global governance? Radical uncertainty is prompting action, evident in new pathways through, and perhaps even beyond, multilateral gridlock (Hale and Held, this section). For many observers, accelerating such efforts is vital if systemic crisis is to be averted. Widening opportunities for system participation and debate, conducted in a spirit of openness and without fear of political conflict, may prove particularly important (Zürn, this section).

In these unsettled times, a huge question mark hangs over the future trajectory of global governance. The academic community has an important role to play in identifying and evaluating transferable tools, mechanisms, and theories which can underpin a viable global public policy delivery model, drawing lessons from 'really-existing global governance arrangements where they are effective' (Marx and Wouters, this section p. \#\#). Reflecting the urgency of the endeavour, as Hale and Held (this section, p. \#\#) note, 'it is vital that we make significant and strategic changes before tragedies unfold'. Scholars should remain mindful of the pitfalls of shallow analysis which tracks too closely to the conventional wisdom (Hurrell, 2011). As Haufler (this section, p. \#\#) cautions, an 'emphasis on 'governance gaps' must not blind us to how the absence of governance can be a deliberate choice imposed by powerful actors even in the face of need. It is also vital that global governance scholars put their shoulder to the wheel of innovating coherent alternatives to old governance models, taking seriously complex geopolitical and organisational realities, but without losing sight of the ultimate global public policy goal: collective action on an unprecedented scale. 


\section{References}

Acharya, A. (2014) 'Global International Relations (IR) and Regional Worlds', International Studies Quarterly, 58 (4), pp. 647-659. DOI: 10.1111/isqu.12171.

Abbott, K. W. (2005) 'Toward a Richer Institutionalism for International Law and Policy', Journal of International Law \& International Relations, 1 (1-2), pp. 9-34.

Abbott, K. W., Keohane, R. O., Moravcsik, A., Slaughter, A. and Snidal, D. (2000) 'The Concept of Legalization', International Organization, 54 (3), pp. 401-419. DOI: 10.1162/002081800551271.

Abbott, K. W., Genschel, P., Snidal, D. and Zangl, B. (eds.) (2015) International Organizations as Orchestrators. Cambridge: Cambridge University Press.

Abbott, K. W., Green, J. F. and Keohane, R. O. (2016) 'Organizational Ecology and Institutional Change in Global Governance', International Organization, 70 (2), pp. 131. DOI: $10.1017 / \mathrm{S} 0020818315000338$.

Abbott, K. W., Levi-Faur, D. and Snidal, D. (2017) 'Theorizing Regulatory Intermediaries: The RIT Model', The Annals of the American Academy of Political and Social Science, 670 (1), pp. 14-35.

Albert, M., Buzan, B. and Zürn, M. (eds.) (2013) Bringing Sociology to International Relations: World Politics as Differentiation Theory. Cambridge: Cambridge University Press.

Albert, M., Cederman, L. and Wendt, A. (2010) New Systems Theories of World Politics London: Palgrave Macmillan.

Alter, K. J. and Meunier, S. (2009) 'The Politics of International Regime Complexity', Perspectives on Politics, 7 (1), pp. 13-24. DOI: 10.1017/S1537592709090033.

Avant, D. D., Finnemore, M. and Sell, S. K. (eds.) (2010) Who Governs the Globe? Cambridge: Cambridge University Press.

Biermann, F., Pattberg, P., van Asselt, H. and Zelli, F. (2009) 'The Fragmentation of Global Governance Architectures: A Framework for Analysis', Global Environmental Politics, 9 (4), pp. 14-40. DOI: 10.1162/glep.2009.9.4.14.

Cerny, P. G. (1993) 'Plurilateralism: structural differentiation and functional conflict in the post-cold war world order', Millennium, 22 (1), pp. 27-51.

Coen, D. and Pegram, T. (2015) 'Wanted: A Third Generation of Global Governance Research', Governance, 28 (4), pp. 417-420. DOI: 10.1111/gove.12164.

Coen, D. and Thatcher, M. (2005) 'The New Governance of Markets and Non-Majoritarian Regulators', Governance, 18 (3), pp. 329-346. DOI: 10.1111/j.14680491.2005.00279.x.

Commission on Global Governance (1995) Our global neighbourhood: the report of the Commission on Global Governance. Oxford: Oxford University Press.

Cox, R. W. (1981) 'Social Forces, States and World Orders: Beyond International Relations Theory', Millennium, 10 (2), pp. 126-155. DOI: 10.1177/03058298810100020501.

De Búrca, G., Keohane, R. O. and Sabel, C. (2014) 'Global Experimentalist Governance', British Journal of Political Science, 44 (3), pp. 477-486. DOI: 10.1017/S0007123414000076.

DeLanda, M. (2006) A New Philosophy of Society: Assemblage Theory and Social Complexity. London: Continuum. 
Dingwerth, K. and Pattberg, P. (2006) 'Global Governance as a Perspective on World Politics', Global Governance, 12 (2), pp. 185-203. DOI: 10.5555/ggov.2006.12.2.185.

Eagleton-Pierce, M. (2014) 'The concept of governance in the spirit of capitalism', Critical Policy Studies, 8 (1), pp. 5-21. DOI: 10.1080/19460171.2014.883854.

Farrell, H. and Newman, A. (2015) 'The New Politics of Interdependence: Cross-National Layering in Trans-Atlantic Regulatory Disputes', Comparative Political Studies, 48 (4), pp. 497-526. DOI: 10.1177/0010414014542330.

Finkelstein, L.S. (1995) 'What is Global Governance', Global Governance, 1 (3), pp. 367-372. Finnemore, M. (2014) 'Dynamics of Global Governance: Building on What We Know', International Studies Quarterly, 58 (1), pp. 221-224. DOI: 10.1111/isqu.12095.

Hale, T., Held, D. and Young, K. (2013) Gridlock: Why Global Cooperation is Failing when We Need It Most. London: Polity.

Hale, T. and Held, D. (this special section).

Hall, T. H. and Ross, A. G. (2015) 'Affective Politics after 9/11', International Organization, 69 (4), pp. 847-879. DOI: 10.1017/S0020818315000144.

Haufler, V. (this special section).

Held, D. (1995) Democracy and the Global Order. Stanford, CA: Stanford University Press.

Hurrell, A. (2007) On Global Order. Power, Values and the Constitution of International Society. Oxford: Oxford University Press.

Hurrell, A. (2011) 'The Theory and Practice of Global Governance: The Worst of all Possible Worlds?' International Studies Review, 13 (1), pp. 144-154. DOI: 10.1111/j.14682486.2010.01005.x.

Hurrell, A. (2017) 'Can the Study of Global Governance be De-Centered?', in A. Triandafyllidou (ed.) Global Governance from Regional Perspectives. Oxford: Oxford University Press, pp. 25-44.

Jessop, B. (1998) 'The rise of governance and the risks of failure: the case of economic development', International Social Science Journal, 50 (155), pp. 29-45. DOI: 10.1111/1468-2451.00107.

Jupille, J. and Caporaso, J. A. (1999) 'Institutionalism and the European Union: Beyond International Relations and Comparative Politics', Annual Review of Political Science, 2 (1), pp. 429-444. DOI: 10.1146/annurev.polisci.2.1.429.

Kaldor, M. (2016) 'BREXIT and disintegrating civilisations', openDemocracy [online], 29 June 2016. Available at: https://www.opendemocracy.net/can-europe-make-it/marykaldor/brexit-and-disintegrating-civilisations.

Katzenstein, P. J. and Sil, R. (2008) 'Analytic Eclecticism in the Study of World Politics: Reconfiguring Problems and Mechanisms across Research Traditions', Perspectives on Politics, 8 (2), pp. 411-431. DOI: 10.1017/S1537592710001179.

Keohane, R. O. and Nye, J. S. (1977) Power and Interdependence: World Politics in Transition. Boston: Little, Brown and Company.

King, M. (2016) The End of Alchemy: Money, Banking and the Future of the Global Economy. London: W. W. Norton \& Company.

Koenig-Archibugi, M. and Macdonald, K. (2013) 'Accountability-by-Proxy in Transnational Non-State Governance’, Governance, 26 (3), pp. 499-522. DOI: 10.1111/j.14680491.2012.01609.x. 
Koh, H. H., Abbott, K. W. and Young, O. R. (1992) 'Elements of a Joint Discipline', American Society of International Law, 86, pp. 167-175.

Krisch, N. (2017) 'Liquid authority in global governance, International Theory, 9 (2), pp. 237260. DOI: $10.1017 / \mathrm{S} 1752971916000269$.

Lake, D. A. (2010) 'Rightful Rules: Authority, Order, and the Foundations of Global Governance', International Studies Quarterly, 54 (3), pp. 587-613. DOI: 10.1111/j.1468-2478.2010.00601.x.

Marx, A. and Wouters, J. (this special section).

Mazower, M. (2014) 'Response', International Studies Quarterly, 58 (1), pp. 219-220. DOI: 10.1111 isqu. 12123 .

Mearsheimer, J. J. and Walt, S. M. (2013) 'Leaving theory behind: Why simplistic hypothesis testing is bad for International Relations', European Journal of International Relations, 19 (3), pp. 427-457. DOI: 10.1177/1354066113494320.

Morse, J. C. and Keohane, R. O. (2014) 'Contested Multilateralism', Review of International Organizations, 9 (4), pp. 385-412. DOI: 10.1007/s11558-014-9188-2.

Paris, R. (2015) 'Global Governance and Power Politics: Back to Basics', Ethics \& International Affairs, 29 (4), pp. 407-418. DOI: 10.1017/S0892679415000428.

Pegram, T. and Acuto, M. (2015) 'Introduction: Global Governance in the Interregnum', Millennium, 43 (2), pp. 584-597. DOI: 10.1177/0305829814562017.

Raustiala, K. and Victor, D. G. (2004) 'The regime complex for plant genetic resources', International Organization, 58 (2), pp. 277-309. DOI: 10.1017/S0020818304582036.

Rees, M. (2014) 'The world in 2050 and beyond', New Statesman [online], 26 November 2014. Available at: https://www.newstatesman.com/sci-tech/2014/11/martin-rees-world2050-and-beyond.

Root, H. (2013) Dynamics among Nations: The Evolution of Legitimacy and Development in Modern States. Boston: MIT Press.

Rosenau, J. N. (1995) 'Governance in the Twenty-first Century', Global Governance, 1 (1), pp. 13-43.

Ruggie, J. (1982) 'International regimes, transactions, and change: embedded liberalism in the postwar economic order', International Organization, 36 (2), pp. 379-415.

Snidal, D. (1985) 'Coordination Versus Prisoners Dilemma: Implications for International Cooperation and Regimes', American Political Science Review, 79 (4), pp. 923-942.

Stoker, G. (1998) 'Governance as theory: five propositions', International Social Science Journal, 50 (155), pp. 17-28. DOI: 10.1111/1468-2451.00106.

Staufenberg, J. (2015) 'World Bank treats human rights like 'an infectious disease' says UN expert', The Independent [online], 24 October 2015. Available at: http://www.independent.co.uk/news/world/politics/the-world-bank-treats-human-

rights-like-an-infectious-disease-according-to-un-expert-a6707166.html. Accessed: 12 October 2017.

Strange, S. (1986) Casino Capitalism. New York: Basil Blackwell.

Taylor, C. (2007) A Secular Age. Cambridge: Harvard University Press.

Tiberghien, Y. (2017) 'Reply to Coen and Pegram: The global liberal system is more fragile than you think', The Governance blog [online], 1 November 2015. Available at: https://governancejournal.net/2015/11/01/2291/. Accessed: 12 October 2017. 
Weiss, T. G. and Wilkinson, R. (2014) 'Rethinking Global Governance? Complexity, Authority, Power, Change', International Studies Quarterly, 58 (1), pp. 207-215. DOI: 10.1111/isqu. 12082.

Weiss, T. G. and Wilkinson, R. (2015) 'Change and Continuity in Global Governance', Ethics \& International Affairs, 29 (4), pp. 397-406. DOI: 10.1017/S0892679415000386.

Weiss, T. G. (2011) Thinking about global governance: why people and ideas matter. Abingdon: Routledge.

Wolf, M. (2012) 'The world's hunger for public goods', Financial Times [online], 24 January 2012. Available at: https://www.ft.com/content/517e31c8-45bd-11e1-93f100144 feabdc 0 ?mhq5j=e5.

Young, O. R. (1980) 'International Regimes: Problems of Concept Formation,' World Politics, 32 (3), pp. 331-356.

Zürn, M. (2018, forthcoming) A Theory of Global Governance: Authority, Legitimation and Contestation.

Zürn, M. (this special section).

\section{Endnotes}

${ }^{1}$ For an extensive discussion of a first and second generation of global governance scholarship see: Coen, D. and Pegram, T. (2018, forthcoming) 'Introduction', in D. Coen and T. Pegram (eds.) Major Works Collection: Global Governance II. London: Routledge Press.

${ }^{2}$ For a useful survey of global governance understandings, see: Triandafyllidou, A. (2017) Global Governance from Regional Perspectives, Oxford: Oxford University Press.

${ }^{3}$ Andrew Hurrell in panel discussion, International Studies Association Annual Conference, 19 March 2016. 


\section{Authors*}

David Coen, Global Governance Institute, University College London

Tom Pegram, Global Governance Institute, University College London

\section{Author Biographies}

David Coen is Professor of Public Policy, Head of the Department of Political Science, Director of the School of Public Policy and founding Director of the Global Governance Institute at University College London. Correspondence: d.coen@ucl.ac.uk.

Tom Pegram is Senior Lecturer in Global Governance at the Department of Political Science, University College London. He is also the Deputy Director of the UCL Global Governance Institute. Correspondence: t.pegram@ucl.ac.uk.

\footnotetext{
* Acknowledgements: We would like to thank all of the participants at the symposium 'Situating Global Governance Scholarship: Towards a Third Generation?' held at the Global Governance Institute, University College London in November 2015. We are also grateful to Julia Kreienkamp for excellent research assistance.
} 